\title{
Verónica SIERRA BLAS, Cartas presas. La correspondencia en la Guerra Civil y el franquismo, Marcial Pons, Madrid, 2016. 360 pp. ISBN: 978-84-15963-78-3
}

En este libro, aparte de poder leer de manera sistematizada las cuatro grandes temáticas que lo estructuran -una muy bien teorizada tipología de los documentos manuscritos por las personas encarceladas durante la Guerra Civil y el franquismo; un repaso ordenado del intercambio de cartas entre presos y familiares o amigos en un ambiente atosigante y siempre marcado por la escasez de papel y por el exceso de censura y autocensuras (o miedos); un acercamiento a la funcionalidad (incluso autobiográfica) del lenguaje de la súplica que los presos y las presas dirigen a las autoridades; y una reflexión profunda sobre la complejidad del dolor que destilan las "cartas en capilla"-, también se puede comprobar que Verónica Serra, con maestría y buena pluma, contribuye a enriquecer otras líneas de investigación que son atravesadas por sus Cartas presas.

En efecto. Principalmente vemos en todo su desarrollo y potencialidad una obra que nace del campo de estudio de la profesora Sierra Blas, la historia social de la escritura y de la lectura (en concreto, en los centros de internamiento): un terreno de investigación que desde un punto de visto teórico-metodológico la propia autora, de manera referencial, está contribuyendo a construir en la historiografía española; y un libro que ofrece el resultado de largos años de lecturas de cartas de presos y presas (mil quinientas cartas y muchos documentos oficiales y personales, la mayor parte depositados en archivos públicos y no pocos encontrados tras un laborioso y difícil rastreo por distintas colecciones particulares). Y en otro orden de cosas observamos una doble contribución historiográfica añadida: en primer lugar, se aporta calidad a la mirada de la historiografía de la prisión (con sus interacciones en un campo compartido por las ciencias sociales y las ciencias penales); y en segundo, se engrandece el campo de estudio de la represión durante la Guerra Civil y el franquismo, apostando por historiar aún más y más profundamente la subjetividad y las emociones como objetos de investigación en sí mismos, ya bastante explorados por otros enfoques historiográficos que se han centrado en la experiencia del castigo durante ese período (la memoria y la fuente oral, las biografías, etcétera).

Por lo que respecta a la historiografía de la prisión, tradicionalmente se han escrutado las fuentes normativas y doctrinales, lo que genuinamente empezó a hacer la Historia del Derecho y de las Instituciones. A partir de ahí las investigaciones de historiadores y juristas se fueron enriqueciendo con los fondos de archivo de ámbitos territoriales diversos, en los que se acumulan fuentes judiciales de todo tipo de jurisdicciones antiguas y modernas, mayores y menores, estamentales y especiales, civiles y militares. Más tarde, la historia social (y cultural) reorientó el curso de estos estudios con el fin de remarcar la utilidad de otras 
muchas fuentes cuantitativas y cualitativas, desde las estadísticas y las hemerográficas a las memorialísticas, literarias e iconográficas, todas ellas necesarias para valorar la relevancia de las instituciones punitivas en el cambio histórico, e imprescindibles si lo que se pretende es tomarle el pulso a la vivencia del encarcelamiento. Es en este sentido en el que se ha dado un paso de evidente transcendencia historiográfica gracias a planteamientos y métodos como los de Verónica Sierra con las cartas de las personas encarceladas durante la Guerra Civil y el franquismo. Especialmente sugerente nos parece, sobre todo para el estudio del mundo concentracionario y del trabajo forzado o en cautividad, el enfoque de esas pseudomemorias o "memorias impuestas" que quedaron plasmadas en documentos cuya estructura estaba prefijada de antemano por las autoridades para que los prisioneros relataran su experiencia a efectos de evaluación y clasificación, o en otros escritos que los interesados demandaban a terceras personas que podían avalarlos y apoyarlos para lograr reducciones, revisiones o conmutaciones de penas, tal vez un leve alivio en el régimen de tratamiento o en los destinos y trabajos.

Las "cartas encarceladas" son al mismo tiempo y de la misma manera "escritura y vida", en completa analogía, solapadas, aherrojadas a un destino del que se sienten víctimas. Ni que decir tiene que en ese tipo de cartas palpita la vida. Las "escrituras del yo" siempre emiten memoria, respiran, reverberan en ella los sonidos y los silencios de la experiencia, las manos que las escribieron, las voces que las dictaron. Aunque de sobra sabemos que el pasado se entiende mejor gracias al inevitable conocimiento de la historiografía de los encarcelamientos de guerra y posguerra, en aquellas cartas cautivas y en otros egodocumentos -ruegos y quejas de curso legal, pliegos de descargo y solicitudes administrativas, diarios y autobiografías, boletines manuscritos y denuncias, grafitis y dibujos-, en ese fondo de olvido lleno de memoria, quedarán sin embargo palabras que siempre serán vestigios mucho más preciosos que la historia misma, rastros únicos de miles de nombres sin historia.

Lo más singular y apreciado de las líneas que casi siempre de manera tortuosa escribe un preso en condiciones de extremo control y censura, radica en que, de manera palmaria o escondida, encubriendo sus voluntades en las entrelineas de un lenguaje aparentemente descomprometido (y tal vez despersonalizado al hacer uso de deferencias impostadas e incluso de los convencionalismo propios de los formularios), nos hablan de vidas que sangran por los cuatro costados del "yo mortificado" que nos desveló Erving Goffman en Internados, cuando hablaba de los procesos de desidentificación que sufren los internos en las instituciones totales.

Además de todo lo que aporta y sugiere a los especialistas de la historia social de la prisión y las instituciones punitivas, como ya hemos remarcado, está claro que este libro de Verónica Sierra enriquece el conocimiento de la represión que tuvo lugar durante la Guerra Civil y el régimen de Franco, añadiendo con los documentos producidos por los propios presos y presas durante y después de su cautiverio", una nueva perspectiva, "desde abajo" y "desde dentro" que, en palabras de la autora, sirve de contraste, correctivo y complemento a las formas tradicionales de construir nuestra historia más reciente.

Este libro sistematiza el amplio repertorio de documentos manuscritos que generaban las personas encarceladas, dibujando los espacios de reclusión como "universos gráficos" en los que de puño y letra se libró un combate contra la soledad y el aislamiento y a favor de la resistencia y la denuncia. A favor de un yo completo, identificado. Por lo que se refiere a la correspondencia carcelaria, en realidad el tema central de este libro desde que descubrimos su portada, Verónica Sierra analiza la realidad de la cautividad de aquellas cartas para ir más allá de lo esperado, para cuestionar y valorizar su atormentado discurrir en el tiempo, su validez histórica y por ende también historiográfica. Con ese objetivo, 
además de explicar, usando palabras de Arnaldo Petrucci, la generación de una "comunidad de escribientes" que producía compañerismo y vinculaba a unos presos con otros en redes de interpretación, de sentido, de significación y de afectos, la autora nos lleva hasta el otro lado de todo aquello, haciéndonos inteligible lo que Roger Chartier categorizó como "comunidad de lectores", en este caso entre personas presas y familiares, con sus espacios y sus momentos privados y también colectivos (evocando lecturas en común que hubieron de darse "tanto en los domicilios particulares como en los patios y celdas de las prisiones").

El último capítulo, lamentablemente previsible, nos habla de la importancia en España de un "producto universal", aquel que trasmite el último testimonio personal de una práctica punitiva -la pena de muerte- que en nuestra guerra y en la represión de posguerra se agigantó hasta hacer de lo excepcional una cruel cotidianidad. Por eso adquieren tanta notoriedad las "escrituras últimas", las "escrituras excepcionales", incluso los "panteones de papel" (los que, verbigracia, dan carácter público a las cartas personales de los Mártires de Barbastro y de las Trece Rosas, por hablar de dos casos de ajusticiamientos colectivos que alcanzaron y aún alcanzan una gran notoriedad y trascendencia), es decir, las "cartas en capilla", las "cartas de despedida" que escribieron quienes unas horas después de dirigirse normalmente a sus seres queridos, fueron ejecutados. Aquí se desmenuzan los rasgos, las funciones y hasta las imágenes de esas "cartas de muertos que sólo nos hablan de vida".

Las cartas de los reos de muerte parecen calendarios que marcan el momento en que se detiene la vida. Son las cartas de quienes también al escribirlas se están preparando hasta el último momento para ser valientes y afrontar la muerte, para justificar la fatalidad de la situación tras confirmar con entereza sus ideas. Cartas que se han escrito para que puedan llegar a ser el consuelo de sus destinatarios, a los que se transmite el intenso amor que por ellos sienten los ya muertos, pidiéndoles que no les olviden, y a los que, como si de un testamento material e incluso "espiritual" se tratara, se les hace concesiones, se les pide perdón y se les da consejos para la vida.

No es fácil trasmitir a la vez el orden del método analítico y el desorden de la congoja. Lo sabemos todos los que hemos investigado sobre la pena de muerte. Pero este libro también puede presentarse como un ejemplo de esa manera de historiar y de preparar al lector para ello, a través de una de las fuentes más auténticas, más dolientes y más complejas.

Pedro Oliver Olmo

Universidad de Castilla-La Mancha Pedro.Oliver@uclm.es 